\title{
Integration of Remotely-Sensed Geobotanical and Structural Methods for Hydrocarbon Exploration in West-Central West Virginia
}

\author{
Quarterly Report \\ November 1, 1996 - January 31, 1997
}

Work Performed Under Contract No.: DE-FG21-95MC32159

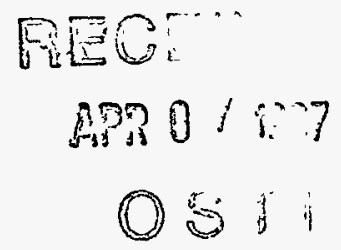

For

U.S. Department of Energy

Office of Fossil Energy

Morgantown Energy Technology Center

P.O. Box 880

Morgantown, West Virginia 26507-0880

DISTRIBUTION OF THIS DOCUMENT IS UNLIMITED

By

Department of Geology and Geography

West Virginia University

P. O. Box 6300

Morgantown, West Virginia 26506-6300

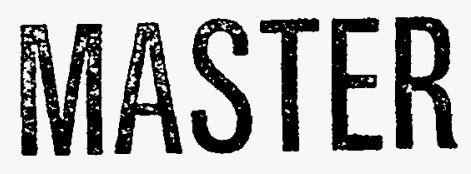




\section{Disclaimer}

This report was prepared as an account of work sponsored by an agency of the United States Government. Neither the United States Government nor any agency thereof, nor any of their employees, makes any warranty, express or implied, or assumes any legal liability or responsibility for the accuracy, completeness, or usefulness of any information, apparatus, product, or process disclosed, or represents that its use would not infringe privately owned rights. Reference herein to any specific commercial product, process, or service by trade name, trademark, manufacturer, or otherwise does not necessarily constitute or imply its endorsement, recommendation, or favoring by the United States Government or any agency thereof. The views and opinions of authors expressed herein do not necessarily state or reflect those of the United States Government or any agency thereof. 


\section{DISCLAMMER}

Portions of this document may be illegible in electronic image products. Images are produced from the best available original document. 


\section{Vegetation spectral library}

The major effort in the last three months has focused reducing the vegetation spectra to a common format, and generating spectral reflectance curves for the data collected in the fall of 1996. Individual graphs are being prepared of each spectrum, as well as composite graphs for each date. The water absorption regions are identified on each graph, and blocked out, to reduce distracting, non-scene variation. Sample spectra are attached to illustrate the work.

Preliminary analysis shows that the fall spectra are of much higher quality than the summer spectra, due to the much lower atmospheric water, and more constant atmospheric conditions. The ratioing nature of the radiometer greatly reduces the problems due to changing atmospheric conditions, but during very hazy periods, atmospheric illumination is actually very low, and consequently the signal received by the spectrometer is very noisy.

\section{Project status}

The majority of the project has been completed now, with final vegetation spectral reflectance data reduction close to completion. So far the following tasks have been carried out:

- Purchase and geo-rectification of multi-temporal imagery

- Comparison of the multi-temporal images for vegetation discrimination

- Digitization of geology (surface and subsurface) and overlay on the images

- Image enhancement for vegetation anomalies

- Lineament analysis

- Soil gas survey, and comparison to lineament analysis

- Vegetation field spectral measurements

The main outstanding issue is to obtain well production data for comparison with the lineaments, soil gas survey and the vegetation anomalies.

Timothy Warner

February 17, 1997 


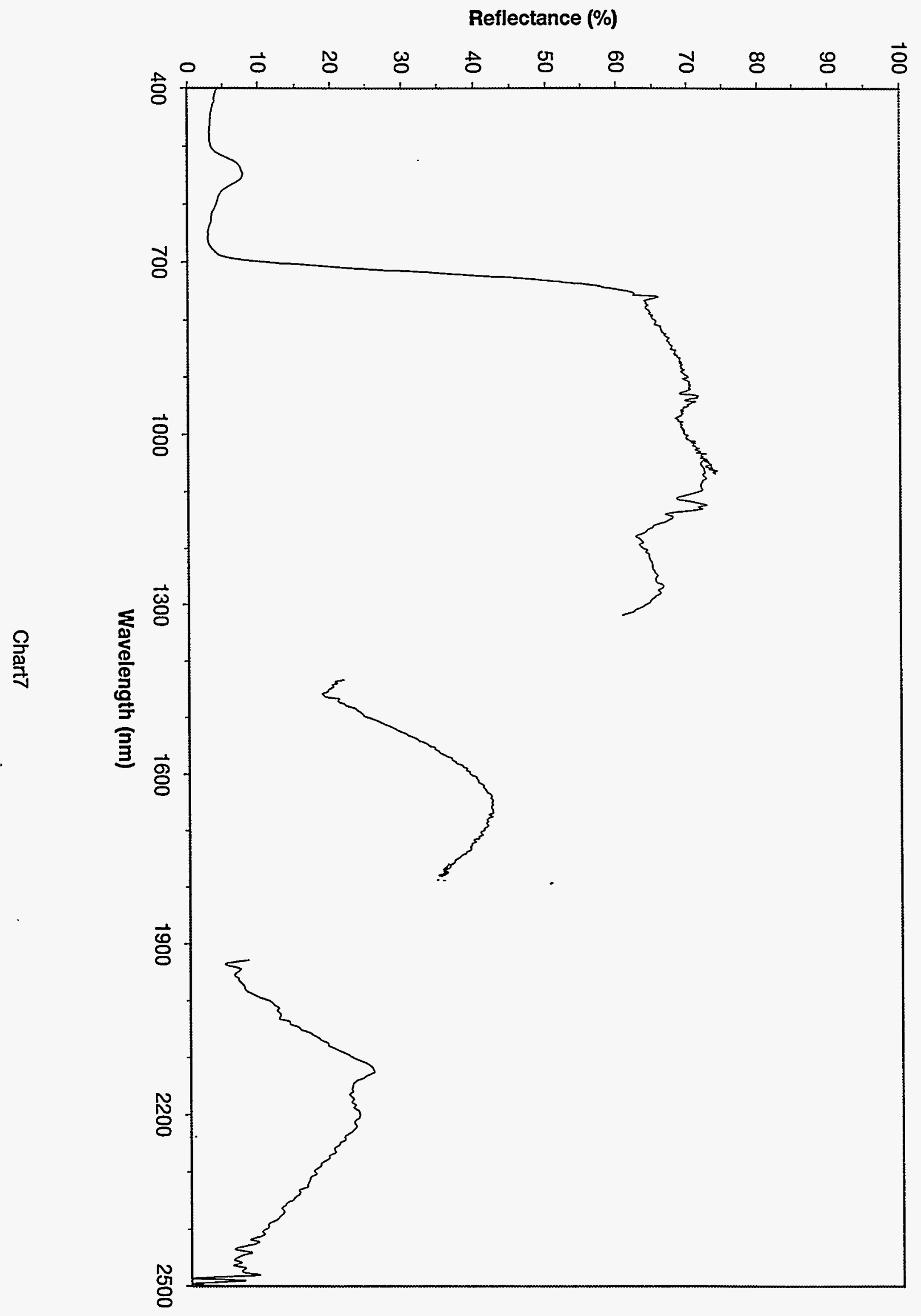

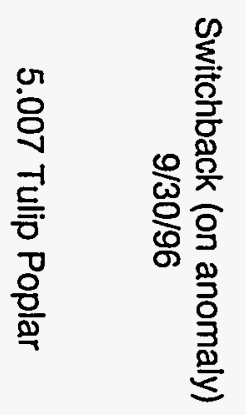


Stonewall Jackson Lake

$C$ Road (off anomaly)

9/30/96

5.003 Tulip Poplar

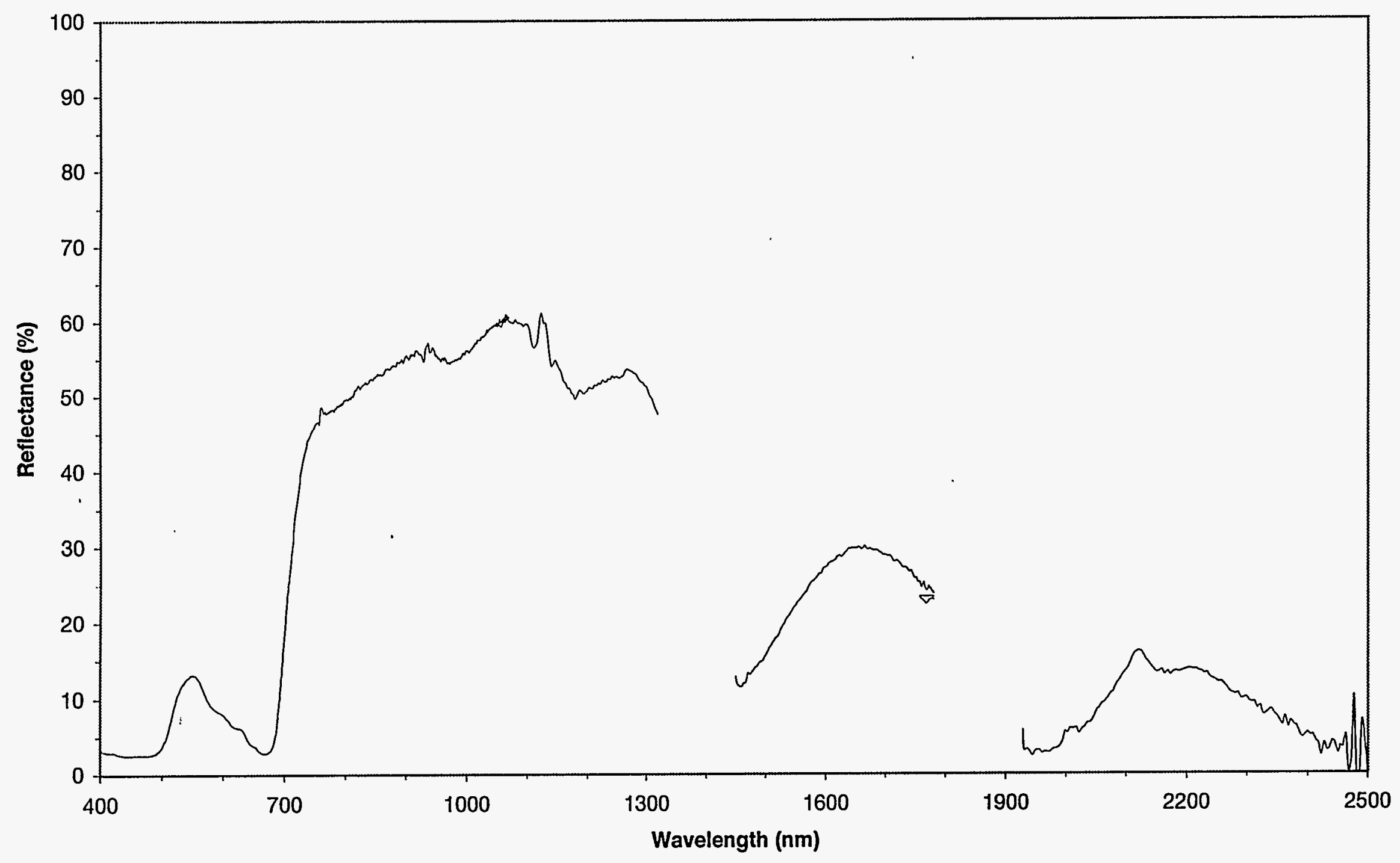

Chart3 


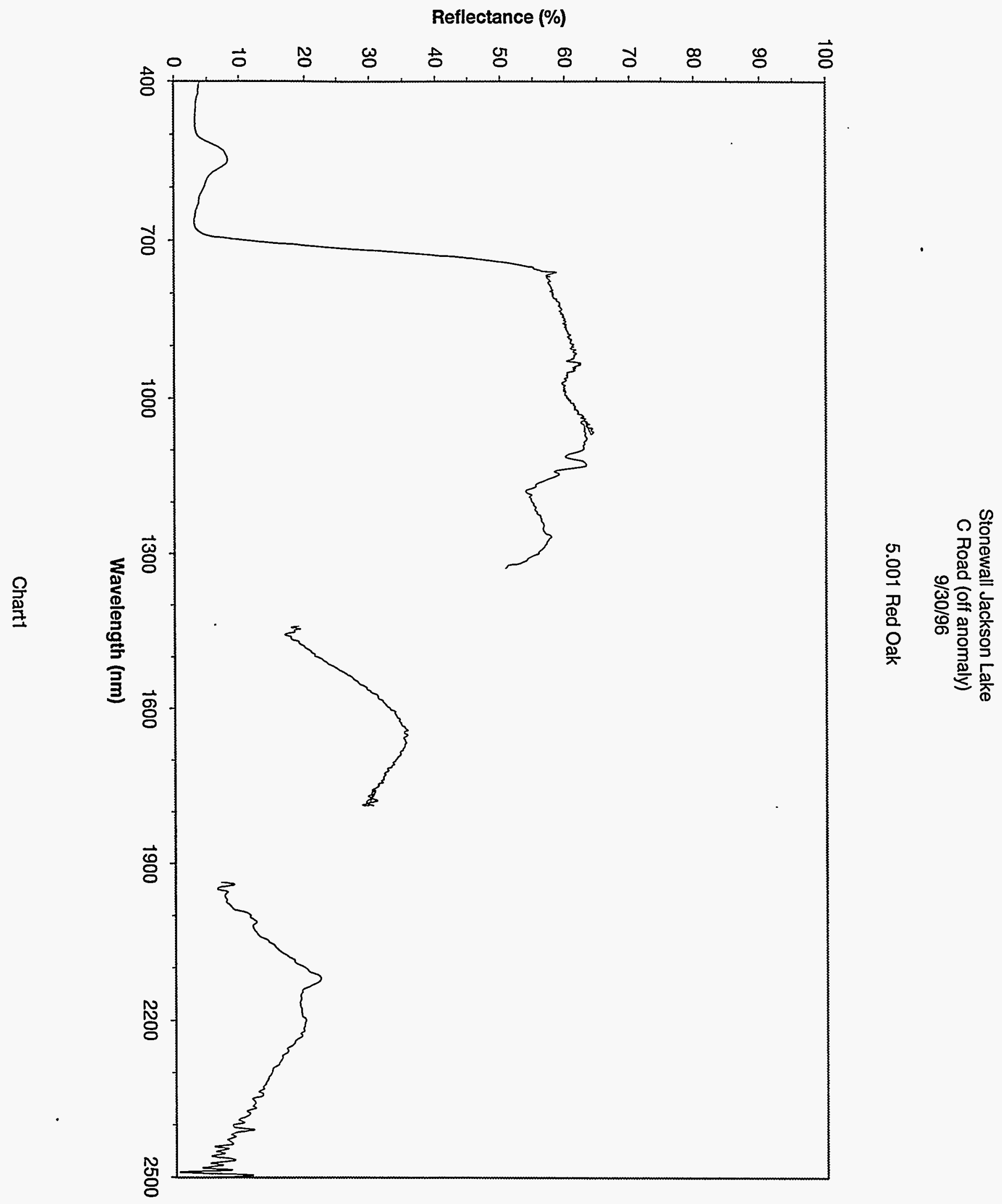


Switchback (on anomaly)

9/30/96

5.008 Red Oak

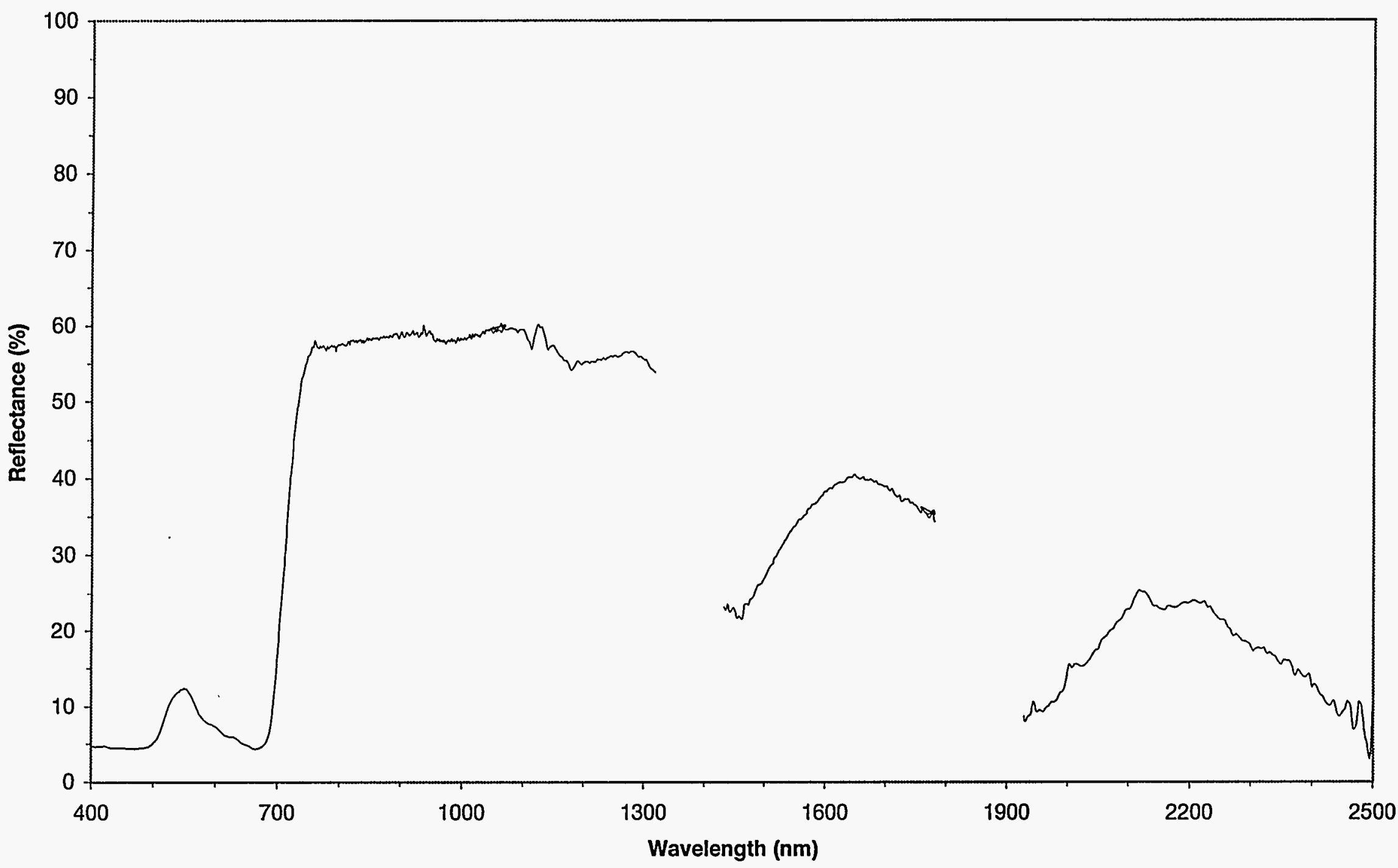

Chart8 